\title{
Characterization of cowpea genotype resistance to Callosobruchus maculatus
}

\author{
Maria de Jesus Passos de Castro(1), Edson Luiz Lopes Baldin(1), Patrícia Leite Cruz ${ }^{(1)}$, \\ Camila Moreira de Souza(1) and Paulo Henrique Soares da Silva(2)
}

\begin{abstract}
(1)Universidade Estadual Paulista, Faculdade de Ciências Agronômicas, Campus de Botucatu, Rua José Barbosa de Barros, no 1.780, Caixa Postal 237, CEP 18610-307 Botucatu, SP, Brazil. E-mail: jesabio@yahoo.com.br, elbaldin@fca.unesp.br, patricialeite@fca.unesp.br, souza_767@hotmail.com (2)Embrapa Meio-Norte, Avenida Duque de Caxias, oㅡ 5.650, Buenos Aires, Caixa Postal 01, CEP 64006-220 Teresina, PI, Brazil. E-mail: paulo.soares-silva@embrapa.br
\end{abstract}

\begin{abstract}
The objective of this work was to characterize the resistance of 50 cowpea (Vigna unguiculata) genotypes to Callosobruchus maculatus. A completely randomized design with five replicates per treatment (genotype) was used. No-choice tests were performed using the 50 cowpea genotypes to evaluate the preference for oviposition and the development of the weevil. The genotypes IT85 F-2687, MN05-841 B-49, MNC99-508-1, MNC99-510-8, TVu 1593, Canapuzinho-1-2, and Sanzi Sambili show non-preference-type resistance (oviposition and feeding). IT81 D-1045 Ereto and IT81 D-1045 Enramador exhibit antibiosis against C. maculatus and descend from resistant genitors, which grants them potential to be used in future crossings to obtain cowpea varieties with higher levels of resistance.
\end{abstract}

Index terms: Vigna unguiculata, Bruchinae, Chrysomelidae, plant resistance, storage.

\section{Caracterização da resistência de genótipos de feijão-caupi a Callosobruchus maculatus}

\begin{abstract}
Resumo - O objetivo deste trabalho foi caracterizar a resistência de 50 genótipos de feijão-caupi (Vigna unguiculata) a Callosobruchus maculatus. Utilizou-se o delineamento inteiramente casualizado com cinco repetições por tratamento (genótipo). Testes de confinamento foram realizados com os 50 genótipos de feijão-caupi, para avaliar a preferência para oviposição e o desenvolvimento do caruncho. Os genótipos IT85 F-2687, MN05-841 B-49, MNC99-508-1, MNC99-510-8, TVu 1593, Canapuzinho-1-2 e Sanzi Sambili apresentam resistência do tipo não preferência (oviposição e alimentação). IT81 D-1045 Ereto e IT81 D-1045 Enramador apresentam antibiose contra $C$. maculatus e descendem de genitores resistentes, o que lhes confere potencial para serem utilizados em futuros cruzamentos, para obtenção de variedades de feijão-caupi com maior nível de resistência.
\end{abstract}

Termos para indexação: Vigna unguiculata, Bruchinae, Chrysomelidae, resistência de plantas, armazenamento.

\section{Introduction}

Cowpea [Vigna unguiculata (L.) Walp.] is a major crop in the North and Northeastern regions of Brazil. This legume has great economic and nutritional importance. Besides its low production costs, due to its short cycle, low water requirement, and ability to survive in inhospitable conditions, such as low fertility soils, it is a key source of proteins and carbohydrates, with a high content in fibers, vitamins, and minerals, as well as a low lipid content (Singh et al., 2002; Freire Filho et al., 2005).

Insect pests that harm the various stages of crop development in the field and that damage stored grains are prominent problems related to cowpea cultivation.
The cowpea weevil Callosobruchus maculatus (Fabr.) (Coleoptera: Chrysomelida, Bruchinae) is considered the most important pest that occurs during the storage period. The attack, which starts before harvest and intensifies during storage, may cause total losses (Faroni \& Sousa, 2006).

The damage by $C$. maculatus is caused by oviposition on the surface of grains and subsequent larval penetration in the grains. The attack results in weight loss, decreased retail and nutritional value, reduced level of product hygiene (presence of droppings, eggs, and insects), and reduced seed germination rate (Almeida et al., 2005; Faroni \& Sousa, 2006).

Chemical control by fumigation has been a common practice in grain disinfestations. However, 
several insect pests have developed resistance to many active ingredients of synthetic products due to failure to comply with usage recommendations, underdosing, and disrespect for the residual period of the insecticides. Furthermore, storage conditions available to most farmers enable re-infestation, increasing the frequency of insecticide use (Almeida et al., 2006).

Conversely, the growing concern about the possible harmful effects of pesticides, such as toxicity to applicators, environmental pollution, and the presence of residues in food, has encouraged investigations on alternative pest-control strategies, including the use of genetically resistant cultivars (Lara, 1991; Panda \& Khush, 1995). This is vital considering the growing expansion of cowpea in the Central-West region of Brazil for exportation to other countries, such as the United States (Freire Filho, 2011), and given the fact that there are no registered products at the Ministry of Agriculture, Livestock and Food Supply for the control of C. maculatus in cowpea (Brasil, 2013).

The use of resistant genotypes is a promising strategy for the management of $C$. maculatus for the following reasons: it can maintain the population of C. maculatus below the economic damage threshold without causing disturbance or pollution to the environment; it does not require specific knowledge by the farmer; it has a low cost; and it is compatible with other means of control, being in accordance with the integrated pest management philosophy (Smith, 2005; Vendramim \& Guzzo, 2009). Some Brazilian studies based on oviposition preference tests (Costa \& Boiça Júnior, 2004) and antibiosis tests (Costa \& Boiça Júnior, 2004; Carvalho et al., 2011) have shown promising results in obtaining cowpea genotypes resistant to $C$. maculatus. However, these studies have only tested a small number of genotypes, and further research is needed to assess a larger variety.

The objective of this work was to characterize the resistance of 50 cowpea (Vigna unguiculata) genotypes to C. maculatus.

\section{Materials and Methods}

The tests were conducted at Laboratório de Resistência de Plantas a Insetos e Plantas Inseticidas from Universidade Estadual Paulista, state of São Paulo, Brazil, from 2010 to 2011. A completely randomized design with five replicates per treatment (genotype) was used. The lines and cultivars used were obtained from the Embrapa Meio-Norte program for the genetic breeding of cowpea. Several of the selected genotypes had been genetically modified for commercial characteristics and resistance to multiple viruses (Table 1).

An initial population of $C$. maculatus was provided through insect breeding in the entomology laboratory of Embrapa Meio-Norte. Clear glass jars with a $500 \mathrm{~mL}$ capacity were used for population multiplication. The jars were closed at the top with a screw cap, where a round hole was made and a 30 mesh nylon screen was adapted to enable internal airing. Each jar was filled with $300 \mathrm{~g}$ of cowpea grains (cultivar BRS Guariba) and maintained under $25 \pm 2^{\circ} \mathrm{C}$, relative humidity of $60 \pm 10 \%$, and photoperiod of 12 hours, in a biochemical oxygen demand (BOD) incubator. The grains contained in these jars were sieved every 28 days, and the newly emerged adults were used in the infestation of the new jars.

After harvesting and processing, the grains were placed in plastic bags and kept in cold storage $\left(2-3^{\circ} \mathrm{C}\right)$ to control potential infestations brought from the field. Prior to performing the tests, the grains were removed from the cold chamber, placed in plastic containers, and stored inside the BOD incubator for ten days to achieve hygroscopic equilibrium.

Oviposition and other biological aspects of the insect were evaluated through no-choice tests in the different genotypes. Based on the method of Costa \& Boiça Júnior (2004), five weevils (unsexed adults) with a maximum age of 48 hours were kept in round plastic containers $(6 \mathrm{~cm}$ diameter by $1 \mathrm{~cm}$ height), with $10 \mathrm{~g}$ of each genotype, for five days, in a BOD incubator, to evaluate oviposition. After that, the insects were removed, and the containers with grains were returned to the same incubator. To avoid crushing the eggs during manipulation and to insure hatching of the larvae, oviposition was quantified 15 days following the initial infestation. This was done by counting the number of viable (white, opaque color) and unviable (hyaline color) eggs per genotype using a stereoscopic microscope 
Table 1. List of the 50 cowpea (Vigna unguiculata) genotypes and their respective genealogies used in the assays for resistance against Callosobruchus maculatus.

\begin{tabular}{|c|c|}
\hline Genotype & Genealogy/Origin \\
\hline BR 14-Mulato ${ }^{(1)}$ & $\mathrm{CNC} 0434 \times \mathrm{CNCx} 27-2 \mathrm{E}$ \\
\hline BR 17-Gurguéia ${ }^{(1)}$ & BR 10-Piauí x CE-315 \\
\hline BR 3-Tracuateua ${ }^{(1)}$ & Selected from the local cultivar Quebra cadeira or Cheque ouro originated from Northeastern Brazil \\
\hline BRS Cauamé(1) & TE93-210-13F x TE96-282-22G \\
\hline BRS Milênio ${ }^{(1)}$ & Selected from cultivar BR 3-Tracuateua \\
\hline BRS Novaera ${ }^{(1)}$ & TE97-404-1F x TE9-404-3F \\
\hline BRS Pajeu $^{(1)}$ & CNCx405-17F x TE94-268-3D \\
\hline BRS Paraguaçu $^{(1)}$ & BR 10-Piauí x Aparecido Moita \\
\hline BRS Potengi ${ }^{(1)}$ & TE96-282-22E x TE93-210-13F \\
\hline BRS Rouxinol $^{(1)}$ & TE86-75-57E x TEx1-69E \\
\hline BRS Tumucumaque $^{(1)}$ & TE96-282-22G x IT87 D-611-3 \\
\hline BRS Urubuquara $^{(1)}$ & Selected from cultivar BR 3 (Tracuateua) \\
\hline BRS Marataoã $\tilde{a}^{(1)}$ & Seridó x TVx 1836-013J \\
\hline Canapuzinho ${ }^{(1)}$ & Local cultivar São Raimundo Nonato, Piauí, Brazil \\
\hline Canapuzinho-1-2(1) & Selected from the cultivar Canapuzinho - São Raimundo Nonato, Piauí, Brazil \\
\hline Capela $^{(1)}$ & Local cultivar Capela do Alto, São Paulo, Brazil \\
\hline Corujinha $^{(1)}$ & Local cultivar Barbalha, Ceará, Brazil \\
\hline Epace $10^{(1)}$ & Seridó x TVu 1888 \\
\hline Inhuma $^{(1)}$ & Selected from the local cultivar Inhuma - Inhuma, Piauí, Brazil \\
\hline Monteiro $^{(1)}$ & Selected from the local cultivar Monteiro - Piripiri, Piauí, Brazil \\
\hline Patativa $^{(1)}$ & $\mathrm{CNC} 1735 \times(\mathrm{CNCx} 926-4 \mathrm{~F} \times$ Paulista $)$ \\
\hline Paulistinha $^{(1)}$ & Local cultivar Barbalha, Ceará, Brazil \\
\hline Pingo-de-ouro-1-1 $1^{(1)}$ & Selected from the local cultivar Pingo-de-ouro - Iguatu, Ceará, Brazil \\
\hline \multirow[t]{2}{*}{ Poços de Caldas, $\mathrm{MG}^{(1)}$} & Selected from the cultivar introduced through undefined screening \\
\hline & from Peru, most likely the cultivar Vainablanca \\
\hline Sanzi Sambili ${ }^{(1)}$ & International Institute of Tropical Agriculture (IITA), Ibadan, Nigeria \\
\hline Vainablanca $^{(1)}$ & Improved cultivar from Peru \\
\hline IT81 D-1045 Enramador ${ }^{(2)}$ & International Institute of Tropical Agriculture (IITA), Ibadan, Nigeria \\
\hline IT81 D-1045 Ereto ${ }^{(2)}$ & International Institute of Tropical Agriculture (IITA), Ibadan, Nigeria \\
\hline IT82 D-889(2) & International Institute of Tropical Agriculture (IITA), Ibadan, Nigeria \\
\hline IT85 F-2687 $(2)$ & International Institute of Tropical Agriculture (IITA), Ibadan, Nigeria \\
\hline IT86 D-716-1 ${ }^{(2)}$ & International Institute of Tropical Agriculture (IITA), Ibadan, Nigeria \\
\hline MN05-841 B-49 (2) & MNC00-599 F-9 x MNC99-537 F-14-2 \\
\hline MNC04-786 B-87-2(2) & MNCOI-625E-10-1-2 5 x MNC99-554 D-10-1-2-2 \\
\hline MNC99-505 G-11 (2) & Canapuzinho x BR 17-Gurguéia \\
\hline MNC99-507 G-4(2) & BR 14-Mulato x Canapuzinho \\
\hline MNC99-507 G-8 ${ }^{(2)}$ & BR 14-Mulato x Canapuzinho \\
\hline MNC99-508-1(2) & TE90 180 88F x Canapuzinho \\
\hline MNC99-510 G-16 ${ }^{(2)}$ & Paulista x TE90-180-88F \\
\hline MNC99-541 F-15(2) & TE93-210-13F x TE96-282-22G \\
\hline MNC99-541 F-21(2) & TE93-210-13F x TE96-282-22G \\
\hline TE93-244-23 F-1 $1^{(2)}$ & IPA 206 x TE86-73-3G \\
\hline TE94-309 G-9(2) & CNCx405-24F x CNCx698-128G \\
\hline TE97-299 G-24(2) & CNCx405-17F x CNCx698-128G \\
\hline TE97-304 G-4 ${ }^{(2)}$ & CNCx405-17F x TE94-268-3D \\
\hline TE97-309 G-18 ${ }^{(2)}$ & CNCx405-24F x CNCx698-128G \\
\hline TE97-309 G-24(2) & CNCx405-24F x CNCx698-128G \\
\hline TVu $1593^{(2)}$ & International Institute of Tropical Agriculture (IITA), Ibadan, Nigeria \\
\hline TVu $36^{(2)}$ & International Institute of Tropical Agriculture (IITA), Ibadan, Nigeria \\
\hline TVu $382^{(2)}$ & International Institute of Tropical Agriculture (IITA), Ibadan, Nigeria \\
\hline
\end{tabular}

${ }^{(1)}$ Cultivar. ${ }^{(2)}$ Line. CNC, Centro Nacional Caupi; MNC, Meio Norte Caupi. 
(20 x magnification). The plots were returned to the BOD incubator until the emergence of the adult insects.

The plots were evaluated daily by sieving the grains of each container through an appropriate mesh and counting the number of insects emerging per day and per genotype, in order to assess the total number of insects emerged and the development period (egg to adult) at 25 days after the initial infestation. After counting, the emerged adults were placed in glass vials $(2 \mathrm{~cm}$ diameter by $5 \mathrm{~cm}$ height) with rubber stoppers, immediately placed in a freezer for rapid death (avoiding weight loss), and maintained under conservation conditions.

Once the emergences ended (i.e., five consecutive days without emergence), the vials containing the emerged insects were opened and placed in an oven $\left(40^{\circ} \mathrm{C}\right)$ for two days; after this period, the dry weight (mg) of the emerged adults was assessed using a precision scale $(0.0001 \mathrm{~g})$. The weighted mean calculated by the formula $\sum x f / \sum x$, in which: $x$ is the number of adults emerging that day and $\mathrm{f}$ is the number of emergence days - was used to determine the egg to adult development period (Costa \& Boiça Júnior, 2004). The dry mass ( $g$ ) of grains consumed by the larvae of all evaluated plots was calculated as the difference between the dry mass of uninfested and infested aliquots, divided by the number of adults emerging from each replicate of the corresponding treatment.

The obtained data were subjected to analysis of variance using the $\mathrm{F}$ test. The normality and homogeneity of the data were assessed with the Kolmogorov-Smirnov and Levene tests, respectively. Whenever the $\mathrm{F}$ test was significant, means were compared by the Scott \& Knott test, at $5 \%$ probability, using the statistical software Sisvar, version 5.0 (Lavras, MG, Brazil).

\section{Results and Discussion}

No significant difference was observed between the genotypes as to the total number of eggs (Table 2). Regarding the percentage of viable eggs, the genotypes Sanzi Sambili, MN05-841 B-49, MNC99-508-1, and Canapuzinho-1-2 had the lowest means, whereas the genotypes MNC99-510 G-16, BRS Novaera, IT82 D-889, Monteiro, IT81
D-1045 Ereto, BRS-Marataoã, BR 17-Gurguéia, BR 3-Tracuateua, BR 14-Mulato, BRS Milênio, and BRS Urubuquara showed the highest percentages.

Seed physical characteristics, such as color, texture, size and hardness, are associated with the resistance of some varieties of cowpea to C. maculatus, as indicated by decreased oviposition (Gbaye \& Holloway, 2011). However, most studies have only recorded the type of resistance and not investigated its causes (Costa \& Boiça Júnior, 2004; Carvalho et al., 2011; Marsaro Junior \& Vilarinho, 2011).

In the present study, a great diversity was observed in grain color (red, green, brown, white, and black tegument) and size (small, medium, and large) among the 50 tested genotypes, but there was little diversity in texture (only one genotype had rough seed coats). Grain color, size, and texture did not interfere in oviposition preference since no significant differences were found among genotypes or in egg viability: the genotypes with the lowest and highest egg viability shared common physical characteristics. The low egg viability may have been due to biochemical factors of the seed coat and the inside of the grain, independently of grain size or texture.

The genotypes Sanzi Sambili, Canapuzinho-1-2, MN05-841 B-49, and MNC99-508-1 presented reductions in the number of adult emergence, which was expected due to the low egg viability. However, it should be highlighted that IT81 D-1045 Ereto, IT81 D-1045 Enramador, and IT85 F-2687, even with high percentages of viable eggs, had decreased number of emergences (less than 35 individuals). The remaining genotypes displayed a high emergence number, which did not differ significantly between the genotypes (Table 2). The IT81 D-1045 genotype descends from TVu 2027, which was selected from the germplasm bank of the International Institute of Tropical Agriculture, used by improvement programs to obtain resistant varieties. The resistance of these genotypes has been associated with variant forms of the reserve protein, vicilin, which cannot be metabolized by the insect's midgut proteinases, limiting the larvae's food supply and interfering with the development of C. maculatus (Domingues et al., 2006). This may have been the case in the present study in 
Table 2. Mean \pm standard error values of total number of eggs, egg viability, number of emerged adults, and viability of the immature phase of Callosobruchus maculatus in different cowpea (Vigna unguiculata) genotypes ${ }^{(1)}$.

\begin{tabular}{|c|c|c|c|c|}
\hline Genotype & Total number of eggs ${ }^{\mathrm{ns}}$ & Egg viability (\%) & Number of emerged adults & Viability of immature phase (\%) \\
\hline IT85 F-2687 & $41.33 \pm 10.89$ & $84.77 \pm 9.08 \mathrm{~d}$ & $34.00 \pm 8.08 \mathrm{a}$ & $96.77 \pm 3.23 \mathrm{e}$ \\
\hline Monteiro & $76.60 \pm 13.99$ & $91.75 \pm 1.31 \mathrm{e}$ & $64.60 \pm 11.99 \mathrm{a}$ & $92.13 \pm 2.16 \mathrm{e}$ \\
\hline MNC04-786 B-87-2 & $82.00 \pm 15.09$ & $79.75 \pm 1.88 \mathrm{~d}$ & $53.00 \pm 10.16 \mathrm{a}$ & $82.58 \pm 3.37 \mathrm{~d}$ \\
\hline MNC99-510 G-16 & $82.00 \pm 16.24$ & $89.39 \pm 3.99 \mathrm{e}$ & $66.80 \pm 13.41 \mathrm{a}$ & $91.69 \pm 3.00 \mathrm{e}$ \\
\hline BRS Milênio & $89.80 \pm 16.56$ & $94.39 \pm 1.74 \mathrm{e}$ & $81.00 \pm 14.45 b$ & $96.47 \pm 4.95 \mathrm{e}$ \\
\hline TVu 36 & $90.40 \pm 17.29$ & $70.00 \pm 2.89 \mathrm{c}$ & $46.20 \pm 9.77 \mathrm{a}$ & $72.75 \pm 2.00 \mathrm{c}$ \\
\hline MNC99-541 F-15 & $93.00 \pm 21.16$ & $81.02 \pm 1.65 \mathrm{~d}$ & $71.20 \pm 15.49 \mathrm{a}$ & $94.94 \pm 3.40 \mathrm{e}$ \\
\hline BRS Xiquexique & $93.60 \pm 09.10$ & $70.09 \pm 4.09 \mathrm{c}$ & $58.60 \pm 8.35 \mathrm{a}$ & $87.65 \pm 4.46 \mathrm{~d}$ \\
\hline Paulistinha & $97.00 \pm 11.82$ & $73.79 \pm 2.60 \mathrm{c}$ & $60.00 \pm 7.82 \mathrm{a}$ & $84.00 \pm 2.26 \mathrm{~d}$ \\
\hline BRS Rouxinol & $97.40 \pm 19.37$ & $87.95 \pm 2.35 \mathrm{~d}$ & $78.20 \pm 17.47 \mathrm{~b}$ & $89.04 \pm 2.10 \mathrm{e}$ \\
\hline MNC99-508-1 & $97.80 \pm 24.15$ & $57.96 \pm 4.54 \mathrm{a}$ & $44.40 \pm 13.76 \mathrm{a}$ & $72.12 \pm 1.28 \mathrm{c}$ \\
\hline BRS Pajeu & $100.80 \pm 20.18$ & $85.82 \pm 3.61 \mathrm{~d}$ & $74.60 \pm 16.71 \mathrm{~b}$ & $84.68 \pm 2.25 \mathrm{~d}$ \\
\hline BRS Cauamé & $101.40 \pm 24.59$ & $84.41 \pm 3.99 \mathrm{~d}$ & $84.00 \pm 24.02 b$ & $96.15 \pm 2.72 \mathrm{e}$ \\
\hline TE97-304 G-4 & $102.20 \pm 16.37$ & $73.16 \pm 1.75 \mathrm{c}$ & $67.20 \pm 11.12 \mathrm{a}$ & $90.11 \pm 3.25 \mathrm{e}$ \\
\hline MNC99-507 G-4 & $102.40 \pm 22.16$ & $75.20 \pm 4.38 \mathrm{c}$ & $53.40 \pm 11.08 \mathrm{a}$ & $71.19 \pm 1.09 \mathrm{c}$ \\
\hline BR 3-Tracuateua & $102.60 \pm 18.69$ & $95.04 \pm 1.30 \mathrm{e}$ & $79.00 \pm 13.72 b$ & $82.73 \pm 1.63 \mathrm{~d}$ \\
\hline TE97-309 G-18 & $102.80 \pm 36.30$ & $82.09 \pm 5.57 \mathrm{~d}$ & $75.40 \pm 27.55 b$ & $94.29 \pm 3.20 \mathrm{e}$ \\
\hline TVu 1593 & $103.20 \pm 11.11$ & $62.04 \pm 1.39 \mathrm{~b}$ & $43.80 \pm 5.88 \mathrm{a}$ & $67.99 \pm 2.41 \mathrm{c}$ \\
\hline BRS Tumucumaque & $103.40 \pm 15.80$ & $65.26 \pm 5.11 \mathrm{~b}$ & $60.20 \pm 10.09 \mathrm{a}$ & $88.65 \pm 3.04 \mathrm{~d}$ \\
\hline Canapuzinho & $105.60 \pm 14.40$ & $87.73 \pm 3.36 \mathrm{~d}$ & $79.20 \pm 11.78 b$ & $85.14 \pm 3.12 \mathrm{~d}$ \\
\hline IT86 D-716-1 & $106.20 \pm 26.56$ & $69.65 \pm 1.36 \mathrm{c}$ & $64.40 \pm 15.30 \mathrm{a}$ & $88.50 \pm 2.54 \mathrm{~d}$ \\
\hline MNC99-541 F-21 & $106.80 \pm 12.08$ & $68.59 \pm 1.68 \mathrm{c}$ & $65.60 \pm 6.06 \mathrm{a}$ & $90.33 \pm 1.50 \mathrm{e}$ \\
\hline BRS Marataoã & $107.80 \pm 20.31$ & $91.33 \pm 1.00 \mathrm{e}$ & $84.00 \pm 16.05 b$ & $84.68 \pm 2.34 \mathrm{~d}$ \\
\hline MNC99-510-8 & $111.40 \pm 43.29$ & $64.78 \pm 3.43 b$ & $48.60 \pm 17.44 \mathrm{a}$ & $69.73 \pm 1.10 \mathrm{c}$ \\
\hline TE97-299 G-24 & $114.00 \pm 32.66$ & $88.19 \pm 1.28 \mathrm{~d}$ & $83.00 \pm 23.39 b$ & $83.24 \pm 0.91 \mathrm{~d}$ \\
\hline Epace 10 & $114.20 \pm 28.50$ & $84.86 \pm 1.86 \mathrm{~d}$ & $88.80 \pm 22.12 b$ & $91.62 \pm 2.97 \mathrm{e}$ \\
\hline TE97-309 G-24 & $115.20 \pm 26.31$ & $87.76 \pm 1.22 \mathrm{~d}$ & $90.40 \pm 19.90 \mathrm{~b}$ & $89.75 \pm 4.75 \mathrm{e}$ \\
\hline BRS Potengi & $116.40 \pm 28.18$ & $66.33 \pm 7.68 b$ & $72.00 \pm 19.44 \mathrm{a}$ & $86.40 \pm 1.74 \mathrm{~d}$ \\
\hline Pingo-de-ouro-1-1 & $116.60 \pm 23.30$ & $69.74 \pm 1.68 \mathrm{c}$ & $59.60 \pm 13.48 \mathrm{a}$ & $72.45 \pm 0.79 \mathrm{c}$ \\
\hline BRS Novaera & $116.60 \pm 22.66$ & $89.04 \pm 2.60 \mathrm{e}$ & $95.00 \pm 20.65 b$ & $89.17 \pm 1.11 \mathrm{e}$ \\
\hline IT81 D-1045 Enramador & $117.20 \pm 17.87$ & $74.60 \pm 3.36 \mathrm{c}$ & $17.60 \pm 4.73 \mathrm{a}$ & $18.63 \pm 11.21 \mathrm{a}$ \\
\hline TVu 382 & $120.00 \pm 21.14$ & $81.37 \pm 3.24 d$ & $85.00 \pm 16.50 \mathrm{~b}$ & $84.49 \pm 4.39 \mathrm{~d}$ \\
\hline Vainablanca & $120.40 \pm 31.65$ & $76.80 \pm 2.32 \mathrm{c}$ & $55.80 \pm 25.93 \mathrm{a}$ & $49.71 \pm 1.78 b$ \\
\hline BR 17-Gurguéia & $120.40 \pm 33.88$ & $95.63 \pm 2.13 \mathrm{e}$ & $102.40 \pm 27.83 b$ & $92.30 \pm 1.64 \mathrm{e}$ \\
\hline Patativa & $122.80 \pm 26.13$ & $84.85 \pm 1.58 \mathrm{~d}$ & $92.00 \pm 18.70 \mathrm{~b}$ & $89.87 \pm 2.19 \mathrm{e}$ \\
\hline MNC99-507 G-8 & $123.00 \pm 32.37$ & $86.76 \pm 3.76 \mathrm{~d}$ & $94.80 \pm 26.40 \mathrm{~b}$ & $87.39 \pm 2.26 \mathrm{~d}$ \\
\hline Sanzi Sambili & $124.20 \pm 26.81$ & $56.38 \pm 3.34 \mathrm{a}$ & $54.00 \pm 12.42 \mathrm{a}$ & $77.30 \pm 1.87 \mathrm{c}$ \\
\hline Poços de Caldas, MG & $126.80 \pm 19.84$ & $74.42 \pm 3.10 \mathrm{c}$ & $74.60 \pm 10.81 \mathrm{~b}$ & $79.73 \pm 1.74 \mathrm{c}$ \\
\hline Canapuzinho-1-2 & $128.20 \pm 21.11$ & $58.53 \pm 2.51 \mathrm{a}$ & $52.20 \pm 9.91 \mathrm{a}$ & $68.58 \pm 1.26 \mathrm{c}$ \\
\hline IT81 D-1045 Ereto & $128.20 \pm 33.20$ & $90.34 \pm 0.81 \mathrm{e}$ & $15.60 \pm 3.80 \mathrm{a}$ & $13.68 \pm 1.27 \mathrm{a}$ \\
\hline Corujinha & $128.40 \pm 06.00$ & $64.77 \pm 3.10 \mathrm{~b}$ & $61.00 \pm 4.95 \mathrm{a}$ & $73.16 \pm 2.94 \mathrm{c}$ \\
\hline TE94-309 G 9 & $130.60 \pm 14.67$ & $76.95 \pm 3.96 \mathrm{c}$ & $85.60 \pm 8.13 b$ & $86.26 \pm 1.85 \mathrm{~d}$ \\
\hline MNC99-505 G-11 & $131.80 \pm 10.34$ & $78.93 \pm 3.81 \mathrm{~d}$ & $85.40 \pm 8.11 \mathrm{~b}$ & $82.40 \pm 3.67 \mathrm{~d}$ \\
\hline BR 14-Mulato & $132.80 \pm 36.69$ & $95.91 \pm 1.95 \mathrm{e}$ & $114.60 \pm 30.05 b$ & $92.34 \pm 3.34 \mathrm{e}$ \\
\hline MN05-841 B-49 & $137.60 \pm 11.31$ & $56.88 \pm 2.54 \mathrm{a}$ & $58.20 \pm 6.77 \mathrm{a}$ & $74.13 \pm 1.21 \mathrm{c}$ \\
\hline Inhuma & $141.20 \pm 32.75$ & $73.34 \pm 3.57 \mathrm{c}$ & $75.40 \pm 17.11 \mathrm{~b}$ & $74.74 \pm 2.63 \mathrm{c}$ \\
\hline BRS Urubuquara & $150.60 \pm 20.48$ & $96.85 \pm 0.86 \mathrm{e}$ & $135.20 \pm 16.77 b$ & $93.47 \pm 1.63 \mathrm{e}$ \\
\hline IT82 D-889 & $153.00 \pm 17.81$ & $89.97 \pm 1.48 \mathrm{e}$ & $118.40 \pm 12.97 \mathrm{~b}$ & $86.35 \pm 1.06 \mathrm{~d}$ \\
\hline Capela & $175.20 \pm 19.28$ & $86.69 \pm 0.92 \mathrm{~d}$ & $128.60 \pm 16.33 b$ & $84.02 \pm 1.61 \mathrm{~d}$ \\
\hline BRS Paraguaçu & $177.80 \pm 33.28$ & $68.91 \pm 3.12 \mathrm{c}$ & $106.20 \pm 24.50 \mathrm{~b}$ & $84.43 \pm 2.67 \mathrm{~d}$ \\
\hline $\mathrm{P}$ & 0.6102 & $<0.001$ & $<0.001$ & $<0.001$ \\
\hline CV (\%) & 45.77 & 8.82 & 49.73 & 8.24 \\
\hline
\end{tabular}

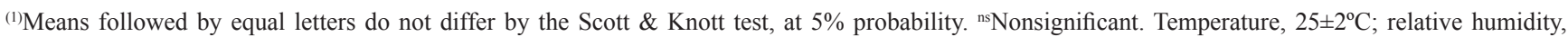
$60 \pm 10 \%$; photoperiod, $12: 12$ hours. 
which both IT81 D-1045 Ereto and IT81 D-1045 Enramador were detrimental to the development of C. maculatus, indicating antibiosis-type resistance.

A possible explanation for the low emergence registered for IT85 F-2687 (Table 2), despite the high percentage of viable eggs, is the fact that this genotype has lower oviposition than the other ones evaluated (although the differences observed were not significant). It should also be noted that IT85 F-2687 was the only one among the tested genotypes with a rough seed coat.

Since the viability of the immature phase directly reflects on the emergence of adults, the lowest percentages recorded in IT81 D-1045 Ereto and IT81 D-1045 Enramador (Table 2) suggest detrimental effects of both of these genotypes for the development of C. maculatus. In contrast, BRS Rouxinol, TE97-309 G-24, BRS Novaera, Patativa, IT85 F-2687, Monteiro, MNC99-510 G-16, BRS Milênio, MNC99-541 F-15, BRS Cauamé, TE97-304 G-4, TE97-309 G-18, MNC99-541 F-21, Epace 10, BR 17-Gurguéia, BR 14-Mulato, and BRS Urubuquara exhibited percentages above $90 \%$. The fact that the egg viability was high in IT85 F-2687 also indicates that the low emergence observed in this genotype did not result from larvae mortality inside the grain.

The genotypes with the highest means for the development period (from egg to adult) were IT81 D-1045 Enramador and IT81 D-1045 Ereto (Table 3), which differed from the other genotypes. In comparison, TE97-309 G-18 and TVu 382 showed the lowest means for the development period, which favored the insect biology. These results are indicative of the expression of antibiosis-type resistance in IT81 D-1045 Enramador and IT81 D-1045 Ereto. The viability and duration of the immature phase are considered important parameters for the characterization of antibiosis to other grain weevils such as Acanthoscelides obtectus Say (Baldin \& Lara, 2008) and Zabrotes subfasciatus Boh. (Baldin \& Pereira, 2010). Moreover, antibiosis-type resistance is characterized by an increased span of time between the egg and adult phases, as well as by the reduction in adult emergence (Costa \& Boiça Júnior, 2004; Smith \& Clement, 2012). Both of these characteristics were observed in the present study. According to Smith
\& Clement (2012), the ability of a resistant host to delay the development of pests results in decreased reproduction rates or number of insects in natural populations due to the increased average time of each generation.

The genotypes with the lowest intake per insect were IT85 F-2687, MNC-99-510-8, BRS Potengi, and BRS Xiquexique, whereas IT81 D-1045 Ereto and IT81 D-1045 Enramador showed the highest mean values of intake per insect (Table 3). The genotypes with lower intake per insect had higher numbers of emerged adults than the ones with higher intake, i.e., lower intake per insect was observed when the viability of the larvae was higher, which may also be related with larvae competition inside the susceptible grains. Another possible explanation for the low intake might be a non-preference-type feeding expression, usually associated with the presence of anti-nutritional or unpalatable compounds, requiring a longer insect feeding period to complete the immature stage (Smith \& Clement, 2012). The higher intakes in IT81 D-1045 Ereto and IT81 D-1045 Enramador confirm antibiosis-type resistance, since the insects feed normally with this resistance mechanism.

No significant differences were observed in insect weight among the genotypes (Table 3). The insects that fed normally did not gain more weight than the ones with low intake. Domingues et al. (2006) studied the survival of $C$. maculatus larvae when grown on IT81 D-1045 resistant seeds and found that the larvae feeding on resistant cowpea embryos developed better than the ones feeding on the cotyledons. Using computed axial scanning (tomography), Tarver et al. (2006) concluded that C. maculatus feeds differently when grown on resistant or susceptible cowpea seeds, and that there is a region in the core of the resistant seeds that has a negative effect on the insect, which avoids this area. This may have been the case in the present study, in which larvae feeding on IT81 D-1045 Ereto and IT81 D-1045 Enramador were not affected in terms of intake, but took more time to develop, being affected in terms of weight gain, possibly due to the ingestion of a detrimental chemical substance, even if in small quantities. The lack of differences in insect weight may also be related to insect metabolism. 
Table 3. Mean \pm standard error values for development period (egg to adult), intake, and dry weight per Callosobruchus maculatus insect in different cowpea (Vigna unguiculata) genotypes ${ }^{(1)}$.

\begin{tabular}{|c|c|c|c|}
\hline Genotype & Development period (days) & Intake per insect $(\mathrm{g})$ & Dry weight per insect (mg) \\
\hline IT81 D-1045 Enramador & $37.04 \pm 0.45 \mathrm{~g}$ & $0.024 \pm 0.005 \mathrm{~d}$ & $1.85 \pm 0.17$ \\
\hline IT81 D-1045 Ereto & $35.01 \pm 1.00 \mathrm{~g}$ & $0.035 \pm 0.005 \mathrm{e}$ & $1.77 \pm 0.03$ \\
\hline BRS-Marataoã & $31.08 \pm 0.37 \mathrm{f}$ & $0.011 \pm 0.001 \mathrm{a}$ & $1.89 \pm 0.08$ \\
\hline BR 3-Tracuateua & $30.31 \pm 0.05 \mathrm{e}$ & $0.014 \pm 0.001 \mathrm{a}$ & $1.96 \pm 0.04$ \\
\hline MNC99-507 G-4 & $30.26 \pm 0.30 \mathrm{e}$ & $0.014 \pm 0.001 \mathrm{a}$ & $1.95 \pm 0.03$ \\
\hline IT82 D-889 & $30.10 \pm 0.20 \mathrm{e}$ & $0.012 \pm 0.001 \mathrm{a}$ & $1.93 \pm 0.06$ \\
\hline MNC99-507 G-8 & $29.96 \pm 0.19 \mathrm{e}$ & $0.013 \pm 0.001 \mathrm{a}$ & $1.99 \pm 0.04$ \\
\hline BRS Cauamé & $29.90 \pm 0.16 \mathrm{e}$ & $0.015 \pm 0.001 \mathrm{~b}$ & $1.98 \pm 0.03$ \\
\hline BRS Novaera & $29.74 \pm 0.22 \mathrm{e}$ & $0.014 \pm 0.001 \mathrm{~b}$ & $1.86 \pm 0.04$ \\
\hline Inhuma & $29.57 \pm 0.27 d$ & $0.018 \pm 0.001 \mathrm{c}$ & $2.33 \pm 0.43$ \\
\hline MNC99-541 F-15 & $28.58 \pm 0.20 \mathrm{~d}$ & $0.011 \pm 0.001 \mathrm{a}$ & $2.00 \pm 0.05$ \\
\hline BR 14-Mulato & $29.54 \pm 0.21 d$ & $0.013 \pm 0.001 \mathrm{a}$ & $1.75 \pm 0.03$ \\
\hline Poços de Caldas, MG & $29.51 \pm 0.27 \mathrm{~d}$ & $0.012 \pm 0.001 \mathrm{a}$ & $1.85 \pm 0.02$ \\
\hline Canapuzinho-1-2 & $29.45 \pm 0.26 \mathrm{~d}$ & $0.015 \pm 0.001 \mathrm{~b}$ & $2.04 \pm 0.08$ \\
\hline Monteiro & $29.44 \pm 0.29 \mathrm{~d}$ & $0.014 \pm 0.001 \mathrm{a}$ & $1.91 \pm 0.02$ \\
\hline Canapuzinho & $29.24 \pm 0.30 \mathrm{~d}$ & $0.015 \pm 0.001 \mathrm{~b}$ & $1.95 \pm 0.04$ \\
\hline MNC99-508-1 & $29.20 \pm 0.28 \mathrm{~d}$ & $0.011 \pm 0.001 \mathrm{a}$ & $1.98 \pm 0.06$ \\
\hline BR 17-Gurguéia & $29.14 \pm 0.37 d$ & $0.011 \pm 0.001 \mathrm{a}$ & $2.06 \pm 0.21$ \\
\hline MN05-841 B-49 & $29.04 \pm 0.44 d$ & $0.013 \pm 0.001 \mathrm{a}$ & $1.82 \pm 0.02$ \\
\hline IT85 F-2687 & $28.96 \pm 0.41 \mathrm{~d}$ & $0.010 \pm 0.001 \mathrm{a}$ & $2.03 \pm 0.66$ \\
\hline MNC99-505 G-11 & $28.84 \pm 0.27 \mathrm{~d}$ & $0.015 \pm 0.001 \mathrm{~b}$ & $2.00 \pm 0.05$ \\
\hline BRS Paraguaçu & $28.80 \pm 0.18 \mathrm{~d}$ & $0.012 \pm 0.001 \mathrm{a}$ & $1.94 \pm 0.08$ \\
\hline BRS Pajeu & $28.80 \pm 0.27 d$ & $0.011 \pm 0.001 \mathrm{a}$ & $2.00 \pm 0.08$ \\
\hline IT86 D-716 1 & $28.75 \pm 0.11 d$ & $0.013 \pm 0.001 \mathrm{a}$ & $1.93 \pm 0.07$ \\
\hline Corujinha & $28.67 \pm 0.12 \mathrm{~d}$ & $0.012 \pm 0.001 \mathrm{a}$ & $1.94 \pm 0.05$ \\
\hline Epace 10 & $28.50 \pm 0.32 \mathrm{c}$ & $0.015 \pm 0.001 \mathrm{~b}$ & $1.93 \pm 0.05$ \\
\hline TE97-299 G-24 & $28.43 \pm 0.19 \mathrm{c}$ & $0.015 \pm 0.001 \mathrm{~b}$ & $2.01 \pm 0.06$ \\
\hline MNC-99-510-8 & $28.42 \pm 0.27 \mathrm{c}$ & $0.010 \pm 0.002 \mathrm{a}$ & $2.04 \pm 0.04$ \\
\hline TE94-309 G-9 & $28.37 \pm 0.15 \mathrm{c}$ & $0.020 \pm 0.001 \mathrm{c}$ & $2.03 \pm 0.02$ \\
\hline BRS Milênio & $28.26 \pm 0.19 \mathrm{c}$ & $0.013 \pm 0.001 \mathrm{a}$ & $1.82 \pm 0.02$ \\
\hline TVu 1593 & $28.22 \pm 0.43 \mathrm{c}$ & $0.020 \pm 0.002 \mathrm{c}$ & $2.09 \pm 0.05$ \\
\hline MNC99-541 F-21 & $28.16 \pm 0.21 \mathrm{c}$ & $0.015 \pm 0.001 \mathrm{~b}$ & $1.94 \pm 0.04$ \\
\hline Pingo-de-ouro-1-1 & $28.07 \pm 0.20 \mathrm{c}$ & $0.016 \pm 0.001 b$ & $1.80 \pm 0.06$ \\
\hline MNC04-786 B-87-2 & $28.06 \pm 0.21 \mathrm{c}$ & $0.018 \pm 0.001 \mathrm{c}$ & $1.93 \pm 0.06$ \\
\hline BRS Rouxinol & $28.04 \pm 0.12 \mathrm{c}$ & $0.014 \pm 0.001 \mathrm{a}$ & $1.86 \pm 0.01$ \\
\hline BRS Potengi & $28.04 \pm 0.42 \mathrm{c}$ & $0.010 \pm 0.002 \mathrm{a}$ & $1.84 \pm 0.07$ \\
\hline BRS Urubuquara & $27.98 \pm 0.28 \mathrm{c}$ & $0.013 \pm 0.001 \mathrm{a}$ & $1.79 \pm 0.02$ \\
\hline Capela & $27.94 \pm 0.20 \mathrm{c}$ & $0.013 \pm 0.001 \mathrm{a}$ & $1.82 \pm 0.03$ \\
\hline Patativa & $27.76 \pm 0.16 \mathrm{c}$ & $0.015 \pm 0.001 \mathrm{~b}$ & $1.93 \pm 0.04$ \\
\hline TE97-304 G-4 & $27.75 \pm 0.12 \mathrm{c}$ & $0.017 \pm 0.001 \mathrm{c}$ & $2.02 \pm 0.06$ \\
\hline Paulistinha & $27.60 \pm 0.19 c$ & $0.017 \pm 0.001 \mathrm{c}$ & $1.95 \pm 0.01$ \\
\hline Sanzi Sambili & $27.57 \pm 0.29 \mathrm{c}$ & $0.018 \pm 0.003 \mathrm{c}$ & $1.77 \pm 0.09$ \\
\hline MNC99-510 G-16 & $27.54 \pm 0.38 \mathrm{c}$ & $0.016 \pm 0.001 \mathrm{~b}$ & $1.95 \pm 0.05$ \\
\hline BRS Xiquexique & $27.41 \pm 0.20 \mathrm{c}$ & $0.010 \pm 0.001 \mathrm{a}$ & $1.95 \pm 0.05$ \\
\hline Vainablanca & $27.09 \pm 0.38 b$ & $0.008 \pm 0.001 \mathrm{a}$ & $1.60 \pm 0.11$ \\
\hline BRS Tumucumaque & $27.02 \pm 0.08 \mathrm{~b}$ & $0.011 \pm 0.001 \mathrm{a}$ & $1.99 \pm 0.04$ \\
\hline TVu 36 & $26.97 \pm 0.34 \mathrm{~b}$ & $0.012 \pm 0.001 \mathrm{a}$ & $1.83 \pm 0.05$ \\
\hline TE97-309 G-24 & $26.73 \pm 0.19 b$ & $0.015 \pm 0.001 \mathrm{~b}$ & $1.85 \pm 0.04$ \\
\hline TVu 382 & $26.16 \pm 0.28 \mathrm{a}$ & $0.013 \pm 0.001 \mathrm{a}$ & $1.79 \pm 0.04$ \\
\hline TE97-309 G-18 & $25.57 \pm 0.52 \mathrm{a}$ & $0.015 \pm 0.001 \mathrm{~b}$ & $1.96 \pm 0.12$ \\
\hline $\mathrm{P}$ & $<0.001$ & $<0.001$ & 0.2128 \\
\hline CV (\%) & 2.37 & 21.82 & 11.99 \\
\hline
\end{tabular}

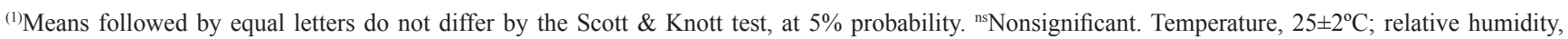
$60 \pm 10 \%$; photoperiod, $12: 12$ hours. 


\section{Conclusions}

1. The genotypes IT85 F-2687, MN05-841 B-49, MNC99-508-1, MNC99-510-8, TVu 1593, Canapuzinho-1-2, and Sanzi Sambili exhibit non-preference-type resistance to the oviposition and feeding of Callosobruchus maculatus.

2. The genotypes IT81 D-1045 Ereto and IT81 D-1045 Enramador exhibit antibiosis-type resistance to C. maculatus.

3. The IT81 D-1045 Ereto and IT81 D-1045 Enramador lines descend from resistant progeny and have potential to be used in future crossings to obtain varieties with higher levels of resistance.

\section{Acknowledgments}

To Conselho Nacional de Desenvolvimento Científico e Tecnológico (CNPq) and to Coordenação de Aperfeiçoamento de Pessoal de Nível Superior (Capes), for financial support and scholarship granted; and to Francisco Rodrigues Freire Filho, for support.

\section{References}

ALMEIDA, F. de A.C.; ALMEIDA, S.A. de; SANTOS, N.R. dos; GOMES, J.P.; ARAÚJO, M.E.R. Efeitos de extratos alcoólicos de plantas sobre o caruncho do feijão vigna (Callosobruchus maculatus). Revista Brasileira de Engenharia Agrícola e Ambiental, v.9, p.585-590, 2005. DOI: 10.1590/ S1415-43662005000400023.

ALMEIDA, S.A. de; ALMEIDA, F. de A.C. de; SANTOS, N.R. dos; MEDEIROS, S.S.A.; ALVES, H. da S. Controle do caruncho Callosobruchus maculatus (Fabr., 1775) (Coleóptera: Bruchidae) utilizando extratos de Piper nigrum L. (Piperaceae) pelo método de vapor. Ciência e Agrotecnologia, v.30, p.793-797, 2006. DOI: 10.1590/S1413-70542006000400029.

BALDIN, E.L.L.; LARA, F.M. Resistance of stored bean varieties to Acanthoscelides obtectus (Coleoptera: Bruchidae). Insect Science, v.15, p.317-326, 2008. DOI: 10.1111/j.1744-7917.2008. 00216.x.

BALDIN, E.L.L.; PEREIRA, J.M. Resistência de genótipos de feijoeiro a Zabrotes subfasciatus (Bohemann, 1833) (Coleoptera: Bruchidae). Ciência e Agrotecnologia, v.34, p.1507-1513, 2010. DOI: $10.1590 / \mathrm{S} 1413-70542010000600022$.

BRASIL. Ministério da Agricultura Pecuária e Abastecimento. AGROFIT. Disponível em: <http://agrofit.agricultura.gov.br/ agrofit_cons/principal_agrofit_cons $>$. Acesso em: 22 ago. 2013.

CARVALHO, R. de O.; LIMA, A.C.S.; ALVES, J.M.A. Resistência de genótipos de feijão-caupi ao Callosobruchus maculatus (Fabr.) (Coleoptera: Bruchidae). Revista Ciência Agronômica, v.5, p.50-56, 2011.
COSTA, N.P. da; BOIÇA JÚNIOR, A.L. Efeito de genótipos de caupi, Vigna unguiculata (L.) Walp., sobre o desenvolvimento de Callosobruchus maculatus (Fabricius) (Coleoptera: Bruchidae). Neotropical Entomology, v.33, p.77-83, 2004. DOI: 10.1590/ S1519-566X2004000100014.

DOMINGUES, S.J.S.; MELO, F.R.; AGUIAR, J.M.; AFFONSO, A.G.; GIULI, J.S.A.; ROSE, J.L.; SALES, M.P.; MACHADO, L.F.; AZEVEDO, C.R.; CUNHA, P.C. da; UCHOA, A.F.; OLIVEIRA, A.E.A. de; XAVIER-FILHO, J.; FERNANDES, K.V.S. Resistance of Vigna unguiculata (cowpea) seeds to Callosobruchus maculatus is restricted to cotyledonary tissues. Journal of the Science of Food and Agriculture, v.86, p.1977-1985, 2006. DOI: 10.1002/ jsfa. 2582 .

FARONI, L.R.A.; SOUSA, A.H. Aspectos biológicos e taxonômicos dos principais insetos-praga de produtos armazenados. In: ALMEIDA, F.A.C.; DUARTE, M.E.M.; MATA, M.E.R.M.C. (Ed.). Tecnologia de armazenagem em sementes. Campina Grande: UFCG, 2006. p.371-402.

FREIRE FILHO, F.R. (Ed.). Feijão-caupi no Brasil: produção, melhoramento genético, avanço e desafios. Teresina: Embrapa Meio-Norte, 2011. 84p.

FREIRE FILHO, F.R.; RIBEIRO, V.Q.; BARRETO, P.D.; SANTOS, A.A. Melhoramento genético. In: FREIRE FILHO, F.R.; LIMA, J.A. de A.; RIBEIRO, V.Q. (Ed.). Feijão-caupi: avanços tecnológicos. Brasília: Embrapa Informação Tecnológica, 2005. p.28-92.

GBAYE, O.A.; HOLLOWAY, G.J. Varietal effects of cowpea, Vigna unguiculata, on tolerance to malathion in Callosobruchus maculatus (Coleoptera: Bruchidae). Journal of Stored Products Research, v.47, p.365-371, 2011. DOI: 10.1016/j. jspr.2011.06.003.

LARA, F.M. Princípio de resistência de plantas a insetos. 2.ed. São Paulo: Ícone, 1991. 336p.

MARSARO JÚNIOR, A.L.; VILARINHO, A.A. Resistência de cultivares de feijão-caupi ao ataque de Callosobruchus maculatus (Coleoptera: Chrysomelidae: Bruchinae) em condições de armazenamento. Revista Acadêmica: Ciências Agrárias e Ambientais, v.9, p.51-55, 2011.

PANDA, N.; KHUSH, G.S. Host plant resistance to insects. Oxon: CAB International, 1995. 431p.

SINGH, B.B.; EHLERS, J.D.; SHARMA, B.; FREIRE FILHO, F.R. Recent progress in cowpea breeding. In: FATOKUN, C.A.; TARAWALI, S.A.; SINGH, B.B.; KORMAWA, P.M.; TAMÒ, M. (Ed.). Challenges and opportunities for enhancing sustainable cowpea production. Ibadan: International Institute of Tropical Agriculture, 2002. p.22-40.

SMITH, C.M. Plant resistance to arthropods. Dordrecht: Springer, 2005. 423p. DOI: 10.1007/1-4020-3702-3.

SMITH, C.M.; CLEMENT, S.L. Molecular bases of plant resistance to arthropods. Annual Review of Entomology, v.57, p.309-328, 2012. DOI: 10.1146/annurev-ento-120710-100642.

TARVER, M.R.; SHADE, R.E.; TARVER, R.D.; LIANG, Y.; KRISHNAMURTHI, G.; PITTENDRIGH, B.R.; MURDOCK, L.L. Use of micro-CAT scans to understand cowpea seed resistance to Callosobruchus maculatus. Entomologia Experimentalis et 
Applicata, v.118, p.33-39, 2006. DOI: 10.1111/j.1570-7458.2006 .00360.x.

VENDRAMIM, J.D.; GUZZO, E.C. Resistência de plantas e a bioecologia e nutrição dos insetos. In: PANIZZI, A.R.;
PARRA, J.R.P. (Ed.). Bioecologia e nutrição de insetos: base para o manejo integrado de pragas. Brasília: Embrapa Informação Tecnológica; Londrina: Embrapa Soja, 2009. p.1055-1105.

Received on June 24, 2013 and accepted on August 29, 2013 